\title{
Income Disparity for Working Mothers: Eliminating Structural Discrimination Through Public Policy
}

Marques Lang

Portland State University

Follow this and additional works at: https://pdxscholar.library.pdx.edu/mcnair Let us know how access to this document benefits you.

\section{Recommended Citation}

Lang, Marques (2011) "Income Disparity for Working Mothers: Eliminating Structural Discrimination Through Public Policy," PSU McNair Scholars Online Journal: Vol. 5: Iss. 1, Article 17. https://doi.org/10.15760/mcnair.2011.50 
Portland State University McNair Research Journal 2011

Income disparity for working mothers: Eliminating structural discrimination through public policy

\author{
by \\ Marques Lang \\ Faculty Mentor: \\ Mary C. King
}

Citation: Lang, Marques. Income disparity for working mothers: Eliminating structural discrimination through public policy. Portland State University McNair Scholars Online Journal, Vol. 5, 2011: pages [63-85] 
Income disparity for working mothers:

Eliminating structural discrimination through public policy

Marques Lang

Mentor: Mary C. King, PhD

Portland State University

Ronald E. McNair Program 


\begin{abstract}
Several studies have shown that in the United States mothers earn lower incomes than employees of similar qualifications and productivity levels. This phenomenon is known as the motherhood penalty. This paper analyzes the antecedents of the motherhood penalty as well as other factors that result in mothers earning lower wages than other women and men, particularly fathers. This begs the question: what role do institutions play in maintaining wage inequality through public policies, specifically maternity leave policy? In answering this question, both the Pregnancy Discrimination Act of 1978 and the Family and Medical Leave Act of 1993 are examined to identify the gaps between current policy and what is needed to promote equality between mothers and nonmothers.
\end{abstract}

\title{
Introduction
}

Many young girls dream of having a family and children of their own once they grow up, however, in the United States this decision may come with several unintended consequences. Mothers in this country are being put into positions that may force them into choosing between their careers, their individual health, and the betterment of their family dynamic, which has the potential to lead to lose-lose situations. When a mother opts to reduce her workload in order to focus her efforts on raising a family she is met with various trade-offs that can hinder her ability to be viewed as a productive worker. If the decision is made to shift to part time work, engage in a flexible schedule, or exit the labor market, the opportunity cost that is associated with such a decision can have a negative affect on a mother's economic status within society due to the financial stability that will be sacrificed in order to 
raise a family.

This lack of economic stability leads to several other problems as well. First, decreased income leads to higher rates of long-term poverty among mothers. This is due to the fact that lower incomes beget diminished contributions to retirement plans and social security, which ultimately leads to smaller income streams for women as they age. Second, children suffer as a result of less time spent with parents, poorer quality of childcare received, or the psychological effects associated with not fitting in with peers who have more financially secure parents. Lastly, to put it bluntly, it simply is not fair for parental status to have any influence on a woman's wages.

Once a woman bears children, she can expect to earn less than males and women without children, regardless of the qualification and productivity levels of the individual worker. This phenomenon is known as the motherhood penalty (Anderson, Binder, \& Krause, 2002; Avellar \& Smock, 2003; Budig \& England, 2001; Crittenden, 2001). Although the extent of the penalty varies, a number of studies that analyzed U.S. National Longitudinal Survey data between 1968-1998 found that there is a motherhood penalty of $4-7 \%$ for one child and an $11-15 \%$ for two or more children (Anderson et al., 2002; Avellar \& Smock, 2003; Budig \& England, 2001; Waldfogel, 1997). This penalty remains present even after accounting for similarities in qualifications such as workforce experience and education as well as organizational commitment and productivity levels (Anderson et al., 2002; Avellar \& Smock, 2003; Budig \& England, 2001; Waldfogel, 1997). 


\section{Who is Affected by the Motherhood Penalty?}

The motherhood penalty is an element of the wage differential between women and men that specifically refers to mothers earning less than people who are similar in all other respects, in terms of education, occupation, and previous time in the labor force. Literature shows that mothers who are highly educated, experienced and/or married are subjected to a larger motherhood penalty than mothers who do not share these same statuses (e.g. Blau \& Kahn, 2000; Budig \& England, 2001; Waldfogel, 1997). A woman with a college education and substantial work experience will typically earn a higher salary than someone with only a high school diploma; therefore, women who reach this status have more to lose post childbearing. Conversely, women whose human capital factors are less significant typically earn less, thus a smaller penalty is incurred.

Marital status also plays a significant role due to the perceived increase in family commitments. When a partner is present to share the financial responsibilities, it is more feasible for a parent to stay at home with their small children. Consequently, mothers may have more time available to dedicate to their family as opposed to spending this time trying to advance one's career. On the other hand, unmarried mothers are usually more self-supporting, which makes it more likely that they will dedicate more time to career advancement than married mothers (Green \& Ferber, 2008), although it should be noted that increased effort by single mothers does not necessarily lead to higher earnings due to the aforementioned motherhood penalties. Furthermore, married men are more likely to have increased job commitment, due to the increase in responsibility that a wife 
and children carries. This commitment ultimately leads to increased earnings as a result of newfound pay expectations, given that pay expectations typically grant individuals with higher actualized incomes (Lips \& Lawson, 2009). In addition, some employers may carry beliefs that married men with children both need and deserve higher incomes.

When men become fathers there is a tendency for their wages to increase. This is known as the fatherhood premium. The premium occurs as a result of the perception that fathers are more able to successfully manage work and family, while becoming more productive and committed to the workplace post-fatherhood. This is due to the fact that employers offer fathers larger salaries as a result of the mentality that men are to serve as breadwinners for the family (Correll, Benard and Paik, 2007; Lips \& Lawson, 2009; Mcquillan, Greil, Shreffler, and Tichenor, 2008; Rabin-Margalioth, 2005).

\section{What Factors Influence the Motherhood Penalty?}

A number of studies have analyzed the motherhood penalty, as well as other contributing sources of wage disparity among mothers, from both economic and sociological viewpoints (e.g. Anderson et al., 2002; Blau \& Kahn, 2000; Budig \& England, 2001; Waldfogel, 1997). This has yielded several potential explanations for why American mothers continue to experience economic disadvantages in modern labor markets. This paper will address a number these issues, such as societal and employer roles as well as discrimination in order to investigate how public policy shapes and perpetuates the occurrence of this phenomenon. 


\section{Social Expectations}

Traditionally, women have been seen as a family's primary homemaker; therefore, the social expectation that women will continue to fulfill this role, rather than pursing a career, can contribute to their decisions as they pertain to the labor market. Lips \& Lawson (2009) found that since women have a strong tendency to value family more than men, women are also more likely to make the necessary sacrifices to maintain a functional family dynamic. This may come as a result of society's expectation that mothers are suppose to engage in such activities. Consequently, mothers commonly spend a significant amount of time participating in childcare duties. Since society expects that mothers will automatically make this sacrifice for the family, mothers tend to work fewer hours, take more time off, and/or shift to part-time work with more frequency than fathers (Stroh, Brett \& Reilly, 1992).

Social roles are learned early on in childhood and are reinforced throughout one's normal development cycle. As social roles become engrained, it fosters an environment where each gender is placed into a role that is commensurate with a stereotypical expectation that becomes a norm. For example, fathers are expected to be breadwinners whereas mothers are expected to be homemakers (Eagly, 1987). These roles lead to societal pressures, expectations, and biases that can contribute to the level of career success that is attained among genders due to their attitudes towards these accepted norms (King, 2008). 


\section{Employer Bias}

It appears that employers perceive the commitment and stability of mothers in the workplace to be less than that of nonmothers. This may come as a result of the aforementioned social expectations. If employers expect women to fulfill certain roles in society, it is no wonder that these ideals carry over into the workplace, regardless of whether a woman's actual behavior mirrors these expectations or not. Consequently, a penalty may come as a result of an employer's expectation that mothers are more likely to split their time between work and family in order to invest more heavily in offspring rather than their careers. Employers may believe that this division of time results in decreased organizational commitment and productivity. Correll et al. (2007) believe that employers become jaded by an either/or fallacy, that is, women can either value motherhood or their work life, but they cannot value both; however, Mcquillan et al. (2008) showed that "there is a significant positive association between valuing work success and importance of motherhood for mothers" (p. 487). In other words, valuing work success and motherhood are not mutually exclusive. Despite the acknowledgement that biases are a contributing factor in the extent of the wage gap, little is known about the weight that this factor actually carries in determining wages due to the fact that many employers are not willing to openly admit that they carry a bias toward mothers.

\section{Labor Market Discrimination}

It has been demonstrated that women may be experiencing significant discrimination in the labor market (e.g. Blau \& Kahn, 2000; Budig \& England, 2001). 
This can have a significant impact one's ability to advance within an organization, thus limiting their earning potential. One way in which gender pay differentials are created are through the division in the types of jobs that the genders are likely to be employed, occupational segregation. Typically, there is a significant representation of males in upper level management, manufacturing, and other blue-collar jobs (England, 2005). Conversely, most of the organizational roles that women have traditionally participated in include service, clerical, or caregiver positions such as nurses, teachers and librarians (Blau, Ferber, \& Winkler, 2006; Crittenden, 2001; Hallock 2001). This division in labor proves to be significant due to the fact that female dominated jobs typically pay less than male dominated jobs (England, 2005). Comparable worth, or pay equity, campaigns (discussed below) have attempted to advocate for organizations to pay comparable wages to similar occupations based on the qualifications and responsibilities of the position rather than on whether a job is considered to be male or female dominated.

"Structural discrimination" arises when institutional policies and procedures lead to inequalities among specific groups of people (Lips \& Lawson, 2009, p. 668). Examples of structural discrimination are when organizations implement meager leave policies, refuse to promote individuals who have taken parental leave, fail to provide adequate childcare resources, and/or are unwilling to advertise or explicitly state the criteria for using the family-friendly policies that are already in place. Consequently, mothers may feel as if they must choose between work and family based on factors that are beyond their control. When this occurs, mothers, if financially able, temporarily resolve this conflict by withdrawing from the labor 
market (Gornick, Meyers, \& Ross, 1998); however, not all families can afford for a mother to take extended time off work without pay. Therefore, in the event that mothers continue to work, there is a perception that they will either reduce the amount of hours worked or take more time off when their children are young (Lips \& Lawson, 2009; Stoh et al., 1992; Williams \& Cohen-Cooper, 2004). Other possible explanations for this occurrence are that some mothers, but fewer fathers, may incur a guilty conscience about not being able to dedicate the time they deem necessary for providing adequate care to their offspring. Also, the limited amount of quality childcare facilities could propel mothers to stay at home with more regularity (Green \& Ferber, 2008). In any event, the wage gap continues to be perpetuated disproportionately.

Pay Equity

One of the most prevalent forms of discrimination in the workplace is wage inequality. Pay equity states that a man and a woman are to be paid an equal wage based on an equal value of work as determined by job evaluations regardless of job position (Hallock, 2001). In other words, pay among genders should be determined based on one's identifiable merit rather than on subjective factors. Over the last two decades there have been a number of pay equity campaigns that have pushed for wage equality among the genders. The success of these movements has been moderate at best due to the amount of time that these cases have spent in the court system without significant results. Equality in pay does not frequently occur due to a societal inability to recognize that the skills of women are indeed comparable to their male counterparts. Furthermore, as a result of social expectations, there are 
ideals as to what kinds of work that each gender should be engaged in (e.g. teaching v. construction). Consequently, the roles of women within organizations vary, as a result of the perception that their labor force commitment and ability to ascend through the ranks is significantly lower than that of men (Blau \& Kahn, 2000).

\section{Human Capital}

Human capital refers to an individual's self-investment through on-the-jobtraining, education, medical care, etc. that substantially improves their physical and mental ability to earn a wage (Becker, 1962). Human capital factors such as workforce experience and education allow one to specialize in a particular function within a society. In the labor market this specialization allows an organization and its employees to be more efficient in the completion of tasks, which ultimately leads to increased revenues and wages (Becker, 1985).

Becker (1985) argues that the reasons why human capital factors contribute to the wage gap are due to the choices that individuals make in regard to the market and the household. That is, it would be more logical for each household member to specialize in either household labor or the labor market, due to the increased efficiency that this division brings to the family unit. Since mothers engage in the majority of the home and child care duties, Becker (1985) posits that this reduces the amount of leisure time that mothers are afforded when children are young and require more attention. Increases in the amount of intensive household labor, when mothers also have careers, have the potential to deplete energy levels. This can lead to decreases in productivity, wages, due to a lack of promotion potential, and perhaps a reluctance toward motherhood altogether (McQuillan et al., 2008). 
Secondarily, the amount of time that an individual invests in work-like activities can have a significant impact on their ability to ascend through the organizational ranks. If an employee is more willing to pursue positive education and work longer hours, the likelihood of promotion becomes higher. This level of upward mobility may lead to seniority and an increase in on-the-job training as well as in wage expectations (Budig \& England, 2001; Lips \& Lawson, 2009). When these factors are combined, it is easy to see how this can contribute to higher earnings for these types of employees and lower earnings for those who are not able to invest their efforts in these arenas. Although the choice to invest in one's education is influenced by social norms as well as other factors, the investment in workforce human capital is ultimately decided on by the employer, not the employee; therefore, an employer's perceptions about who to invest in plays a major role on an employee's path of organizational advancement.

Workforce Experience

Another contributing factor to the wage gap is the amount of time that individuals spend in the labor market. In recent years mothers are spending, on average, approximately 4.6 years out of the labor market (Blau \& Kahn, 2000). When there is a gap in employment history one can expect to earn less money upon their return to the workforce due to having to restart a career, the depreciation of job skills, and having fewer contacts within an organization. The wage gap can be further explained by the amount of on-the-job training that one receives because employers may be less willing to devote precious training dollars on those whom they think are more likely to withdraw from the market (Anderson et al., 2002; Blau 
\& Kahn, 2000; Green \& Ferber, 2008). This reduction in skills is especially evident in industries that are continuously evolving in a rapid manner (Blau et al., 2006). Therefore, the gap in employment may lead to men or women without children being promoted to higher status positions within an organization with much more regularity than women with children (Crittenden, 2001). As a result, women with children who remain in the labor market are more likely to experience a glass ceiling, especially as it pertains to upper level jobs (Blau et al., 2006; Crittenden, 2001).

Timing also plays a critical role as to whether mothers are able to obtain work-family balance. It has been stated (Green \& Ferber, 2008; Rabin-Margalioth, 2005 ) that it is more beneficial for women who value both career and family to start families at a younger age, typically before 30 . The reasons for this are threefold: First, the pool of eligible partners tends to be higher at this stage of one's life; therefore, women have greater odds of finding a compatible partner. Second, the pressure involved with the biological clock is minimized, since women are at their most fertile at this point. Lastly, it has been shown that the long-term ramifications associated with earlier labor market interruptions are easier to recover from, whereas exiting later in one's career can cause significantly more harm (Green \& Ferber, 2008; Rabin-Margalioth, 2005). Thurow (1984) explains how difficult the decision can be for women when it comes to choosing between work and family by stating:

The years between 25 and 35 are the prime years for establishing a successful career. These are the years when hard work has the maximum 
payoff. They are also the prime years for launching a family. Women who leave the job market completely during those years may find that they never catch up (p. 83).

\section{Mother Friendly Work}

It would appear as if more mothers are becoming attracted to "motherfriendly" jobs (Budig \& England, 2001, p. 207). Mother-friendly jobs are those that make it easier for a mother to combine work and family and are characterized by flexible work hours, safe work environments, and family-friendly policies (i.e. onsite child care facilities, limited evening and weekend work, etc). When combined, these factors make it easier for mothers to combine work and family. However, there is a cost associated with mother-friendly jobs. That is, since these jobs get categorized as being female jobs, they also get paid as such. This typically means a lower wage due to the perception that jobs that have been identified as femaleoriented (i.e. nurses and teachers) are looked upon as being less valuable than those positions that are classified as male oriented (i.e. management and blue collar jobs) (England, 2005). A further explanation for why these positions are paid less is described below.

\section{Effect on the GDP}

If two-thirds of the wealth in the modern economy is recognized as being based on human capital, and mothers are primarily responsible for the production and nurturing of this capital in the home, it can be argued that the roles of mothers are essential to the development of nations, given that societies benefit from the economic productivity of these future employees (Avellar \& Smock, 2003; Budig \& 
England, 2001; Crittenden, 2001). However, since home duties are not paid monetary transactions, they do not count toward the GDP. If people were to validate the value that mothers create for societies, not only would there be an enormous increase in the GDP, but nations could potentially acknowledge that raising children is the most important job in the world (Crittenden, 2001). Though, it should be noted that this acknowledgement still might not result in the valuing of mothers in the workplace unless their skills are recognized as being valuable.

\section{Policy}

At the public policy level, the United States is in a very unique position in terms of providing adequate benefits to parents. While there are numerous ways to go about enhancing policies to be more family friendly, the focus of this paper will be on leave policies. The two statutes, in the United States, that have had the largest impact on parental leave are the Pregnancy Discrimination Act of 1978 and the Family and Medical Leave Act of 1993 . These statutes will be examined to identify the gaps between current policy and what is needed to promote equality between mothers and nonmothers.

The Pregnancy Discrimination Act (PDA) amended Title VII of the Civil Rights Act of 1964. This amendment made it illegal for employers to discriminate against women on the basis of pregnancy, childbirth, or any other related medical condition. Organizations with 15 or more employees are required to abide by this statute. In addition, employers cannot use pregnancy as a basis for hiring and firing decisions, denying leave and health insurance, or in the limiting of fringe benefits that are available to employees who are not pregnant. Essentially, employees who are or 
become pregnant are treated the same as temporarily disabled employees, and the inequitable treatment of such employees is considered a form of sexual discrimination.

In 1993 the Family and Medical Leave Act (FMLA) was signed into law. The purpose of this law is to provide leave time for employees in order to care for a newborn or adopted child, an elderly parent, or any other family related issue that may arise. This law affects organizations with 50 or more employees. In order for an employee to be eligible for benefits under FMLA, he must have worked at least 1,250 hours in the preceding 12 months with their current organization. If both of these criteria are met then the employee is eligible for up to 12 weeks of unpaid leave per year.

Problems with the FMLA

Although both of these statutes provided a boost in the efforts to promote parental equality in the workplace, there is still a large margin for improvement, especially within the FMLA. Based on the eligibility criteria stated above, only 45\% of U.S. women qualify for this leave (Guthrie \& Ross 1999; Waldfogel, 2001). In 2000 , only $16 \%$ of those who covered by the FMLA used leave, $90 \%$ of which did not exercise their rights to use the full 12 weeks due to a lack of pay while on leave (Waldfogel, 2001). Furthermore, since the Family and Medical Leave Act is only mandatory for businesses with 50 or more employees, there is a portion of the workforce, entrepreneurs and other small business workers, that remain uncovered by the law, which may subject employees to continued abuses that perpetuate the income gap amongst mothers. Lastly, there are a number of employers who do not 
comply with the law (Williams \& Boushey, 2010), thus further continuing this cycle of wage disparity.

The FMLA also has a number of other limitations. First, the act focuses on traditional families. It does not provide shelters for single parent households, who require an income in order to survive. And until 2010, domestic partnerships were also excluded. Second, a third of all employers that are affected by the law were already providing benefits that were equal to or greater than the benefits described in the statute. Lastly, in order to be eligible an employee must have worked 1,250 hours in the preceding 12 months with their current company; however, since many of the lower paid workers typically have either less than one year of experience, work part time or intermittently, or are individuals who have taken leave, they are not eligible for benefits under the FMLA (Williams \& Boushey, 2010).

\section{Proposed changes}

A number of analysts (e.g. Gornick \& Meyers, 2003; Jacobs \& Gerson, 2004; Rabin-Margalioth, 2005; Williams \& Cooper, 2004) have proposed various changes that could potentially aid in reducing the income gap. The most prominent proposals fall into three categories: regulating the workweek, providing benefits to part time employees, and mandating paid leave.

Regulating the workweek can take shape in a couple of different ways. First, policy could create a standardized workweek that would make full time equivalent to 35 hours a week, without any fear of reprisal such as lack of raises, promotions, or bonuses. This would provide individuals with more family and leisure time, which could lead to a more productive workforce, while potentially helping to 
redistribute household labor among genders to more equitable levels (Gornick \& Meyers, 2003; Jacobs \& Gerson, 2004; Rabin-Margalioth, 2005; Williams \& Cooper, 2004). However, this would require changes to the Fair Labor Standards Act. For example, overtime laws would need to be adjusted to start at time worked over 35 hours rather than 40 hours. In addition, exemption criteria would have to be reevaluated in order to provide those in management positions the same treatment as subordinate workers. This would also aid in eliminating the glass ceiling that mothers face as a result of not being able to comply with the demanding work schedules that are expected from mid to upper level managers. Another, and perhaps more feasible, change would be to allow flexible scheduling in terms of days and hours worked as well as start and finish times. Although the impact of this change would be minimal, it could allow for more family time in the mornings and evenings.

Second, since a number of parents, primarily mothers, work on a part time basis, due to the family friendly nature of these jobs, benefits could be given to part time employees. These benefits could include retirement as well as medical insurance and leave benefits at the same cost to the part time employee as to full time employees. It is not uncommon for part time employees to have to incur larger portions of their insurance premiums, if any are even offered, while earning a smaller wage. Providing these benefits at an affordable rate would have a considerable impact on workforce equality. Also, retirement benefits would go a long way to narrowing the long-term income gap. Mothers who either work part time or opt to leave the labor market also lose their retirement contributions. This 
leads to mothers' continued social and economic struggle not only during peak childbearing years but in the golden years as well.

Lastly, mandating paid leave could perhaps have the most significant impact on a parent's ability to adequately care for a child. However, this would require a great deal of compromise between policy makers and organizations. One such way to appease both sides could be to offer a tax incentive to organizations that provide paid leave. This would allow organizations to continue to maintain their bottom line, while providing parents with the income that they require. The reduction in national tax revenue could be made up by the increased number of individuals who remain in the workforce who otherwise would have dropped out. The more people there are in the labor market, the more taxpayers there are in the pool, which is beneficial to all the parties involved.

Policy reform will be of the utmost importance when it comes to remedying pay discrimination against mothers. Of all the industrialized countries in the world, the United States is among the worst when it comes to instituting family friendly parental leave policies (Aisenbrey et al. 2009; Gornick et al., 1998; Williams \& Cooper, 2004). This must change if there is to be pay equality, since there is a strong association between good leave policies and mothers' capacity to reenter and remain active participants in the workforce post-childbearing (Gornick et al., 1998; Guthrie \& Ross, 1999). Furthermore, it has been shown that good policies increase workforce attachment among women, for it allows mothers to better balance work and family life without taking extended withdrawals from the market (Gornick et al., 1998). These types of policies may allow mothers to feel as if their contribution to 
the workplace is valued, in addition to allowing their relationships with the organization and its members to be nurtured. Ultimately, this increase in experience, rather than extended leave from or exiting the market, will provide mothers with higher salaries, thus helping to close the wage gap.

\section{Conclusion}

It goes without stating that mothers play an invaluable role in the development of societies throughout the world. However, in the United States there is an inexplicable under appreciation for the sacrifices that are made on a daily basis by millions of mothers across the country. Mothers are being relegated to traditional gender roles in the home and are experiencing a glass ceiling in the workplace. If wages are truly determined by a "free" market system, one can conclude that the contributions of mothers in this market are perceived to be less valuable than those of fathers, which is contributing to large wage disparities among genders in the labor market (Hallock, 2001). Despite the increases in the number of women who are college educated, they only reap rewards similar to men when they opt to not have children and maintain a continuous presence in the labor market (Blau et al., 2006); however, this alternative too often comes at the expense of one's potential family life. Therefore, a choice that many women must consider is one of family and children, career with minimal family interaction, or the career as a standalone. With that being said, there has been progress made in the past two decades when it comes to women as mothers and workers. In the mid 1980's, it was estimated that women spent approximately 9 years out of the labor market (Hewlett, 1986). In 2000, this gap narrowed to 4.6 years (Blau \& Kahn, 2000). There 
are several factors that could explain this shift such as falling real male wages, favorable public and corporate policies, more opportunities for part time employment, and men sharing more of the household duties.

However, in order to continue to take strides toward greater gender equality in the labor market, while ensuring more work-life balance, a paradigmatic shift in societal thinking must occur. As a society we must begin to realize that the gender income gap is not just a woman or mother problem, but it is a family and cultural issue that affects everyone. The current system has not worked because most families simply cannot afford to take unpaid leave without falling into economic hardship. Therefore, in many instances it is not a choice for mothers to accept lower paying jobs rather it is an obligation in an attempt to make ends meet. In order for progress to be made it will be vital for our society to start enacting the family values that we so frequently espouse to ensure the facilitation of tangible change in our communities moving forward. 


\section{References}

Aisenbrey, S., Evertsson, M., Grunow, D. (2009). Is there a career penalty for mothers' time out? A comparison of Germany, Sweden and the United States. Social Forces, 88(2), 573-605.

Anderson, D. J., Binder, M., \& Krause, K. (2002). The motherhood wage penalty: which mothers pay it and why? American Economic Review. 92, 354-358.

Avellar, S., \& Smock, P. J. (2003). Has the price of motherhood declined over time? A Cross-Cohort Comparison of the Motherhood Wage Penalty. Journal of Marriage and the Family. 65(3), 597-607.

Becker, G. S. (1962). Investing in human capital: A theoretical analysis. Journal of Political Economy, 70(5), 9-49.

Becker, G. S. (1985). Human capital, effort, and the sexual division of labor. Journal of Labor Economics, 3, 33-58.

Blau, F. D., Ferber, M.A., \& Winkler, A.E. (2006). The economics of women, men and work ( $5^{\text {th }}$ ed). Upper Saddle River, NJ: Prentice Hall.

Blau, F., \& Kahn, L. (2000). Gender differences in pay. Journal of Economic Perspectives, 14(4), 75-99.

Budig, M. J., \& England, P. (2001). The wage penalty for motherhood. American Sociological Review. 66 (2), 204-225.

Crittenden, A. (2001). The price of motherhood: why the most important job in the world is still the least valued. New York, NY: Owl Books.

Correll, S. J., Benard, S., \& Paik, I. (2007). Getting a job: Is there a motherhood penalty? American Journal of Sociology. 112 (5), 1297-1338.

Eagly, A.H. (1987). Sex differences in social behavior: A social role interpretation. Hillsdale, NJ: Erlbaum.

England, P. (2005). Gender inequality in labor markets: The role of motherhood and segregation. Social Politics: International Studies in Gender, State \& Society. 12 (2), 264-288.

Ferber, M., \& Young, L. (1997). Student attitudes toward roles of women and men: Is the egalitarian household imminent? Feminist Economics. 3 (1), 65-83.

Gornick, J., Meyers, M., \& Ross, K. (1998). Public policies and the employment of mothers: A cross-national study. Social Science Quarterly, 79(1), 35-54. 
Gornick, J. C., \& Meyers, M. K. (2003). Families that work: Policies for reconciling parenthood and employment. New York, NY: Russell Sage Foundation.

Green, C. A., \& Ferber, M. A. (2008). The long-term impact of labor market interruptions: how crucial is timing? Review of Social Economy. 66 (3), 351379.

Guthrie, D., \& Roth, L. (1999). The state, courts, and maternity policies in U.S. organizations: specifying institutional mechanisms. American Sociological Review, 64(1), 41-63.

Hallock, M. (2001). Pay equity: Did it work? In M.C. King (Ed.), Squaring up: policy strategies to raise women's incomes in the United States (pp. 136-158). Ann Arbor, MI: The University of Michigan Press.

Hewlett, S.A. (1986). A lesser life: The myth of women's liberation in America. New York, NY: Warner Books.

Jacobs, J., \& Gerson, K. (2004). The time divide: Work, family and gender inequality. Cambridge, MA: Harvard University Press.

King, E.B. (2008). The effect of bias on the advancement of working mothers: Disentangling legitimate concerns from inaccurate stereotypes as predictors of advancement in academe. Human Relations. 61 (12), 1677-1711.

Lips H., \& Lawson K. (2009). Work values, gender, and expectations about work commitment and pay: Laying the groundwork for the "motherhood penalty"? Sex Roles. 61 (9), 667-676.

Mcquillan, J., Greil, A., Shreffler, K., \& Tichenor, V. (2008). The importance of motherhood among women in the contemporary United States. Gender \& Society. 22 (4), 477-496.

Rabin-Margalioth, S. (2005). Women, careers, babies: An issue of time or timing? UCLA Women's Law Journal 13(Spring): 293-334.

Stroh, L.K., Brett, J.M. \& Reilly, A.H. (1992). All the right stuff: A comparison of female and male managers' career progression. Journal of Applied Psychology, 77, 251260.

Thurow, L.C. (October 1984). 62 cents to the dollar; the earnings gap doesn't go away. Working Mother, 42.

Waldfogel, J. (1997). The effect of children on women's wages. American Sociological Review. 62(2), 209-217. 
Waldfogel, J. (2001). Family and medical leave: evidence from the 2000 surveys. Monthly Labor Review, 124(9), 17-23.

Williams, J. C., \& Cohen-Cooper, H. (2004). The public policy of motherhood. Journal of Social Issues, 60, 849-865.

Williams, J.C., \& Boushey, H. (2010). The three faces of family conflict: The Poor, the professionals, and the missing middle. Center for WorkLife Law, University of California, Hastings College of the Law and The Center for American Progress, 1-86. 